\title{
Agroforestry for sustainable forage and livestock production in a small-holding farming system
}

\author{
M.R. Alam ${ }^{1}$ and Md. Jahiruddin ${ }^{2}$ \\ Bangladesh Agricultural University, \\ ${ }^{1}$ Deptartment of Animal Science, \\ ${ }^{2}$ Department of Soil Science \\ Mymensingh 2202, Bangladesh
}

\begin{abstract}
Shortages of fodder for livestock are serious constraints to their productivity. The potential of integrating multipurpose leguminous trees into crop and livestock systems was investigated at farm level. The study evaluated the potential to provide high quality fodder for improving livestock production, enhancing soil fertility and generating income in an agroforestry system. Promising results were obtained: production of 7.1 and $0.52 \mathrm{t} / \mathrm{ha} / \mathrm{yr}$ fresh leaves and protein, respectively. Supplementation with these leaves improved by $61 \%$ the milk yield of cows, and by 49 and $68 \%$ the growth of calves and goats, respectively. Additionally, the potential of these trees to provide $34 \%$ of much needed fuel wood, improvement of $36 \% \mathrm{OM}$ and $40 \% \mathrm{~N}$ in soils, and income by $43 \%$ was demonstrated. It is likely that fodder trees will play a major role in meeting the feed demands for livestock, maintenance of soil fertility and agro-ecology by sustainable land use to make the smallholding system more relevant and effective.
\end{abstract}

KEY WORDS: agroforestry, forage, livestock, soil, income

\section{INTRODUCTION}

In cereal-crop dominated agriculture, livestock rearing is considered an important and potential component of sustainable crop-livestock farming. The importance is mainly concentrated on its ability to transform crop wastes and farmyard-grown feed into high quality food, income generation activity, and long-term sustenance of farming systems. Livestock thriving on crop residues and natural vegetation around the farmstead are common features of farming systems. Farmers own land ranging from 1 to 3 ha per family and livestock is

${ }^{1}$ Corresponding author: e-mail: mraisulalam@yahoo.com 
raised for supplementing small holding farms. Cattle are used for milk, meat and as work animals, whereas goats are raised to provide immediate cash income for families.

The arable land is under intensive crop cultivation and livestock rearing is constrained by the availability of land for forages. Any new efforts for livestock improvement should bring significant economic benefit and improve the livelihood of farmers. This would require intervention in cropping systems, which is not a viable proposition for a country producing 1.8 crops per year for a population of 146 million. Systems for improving sustainable forage and livestock production without affecting crop farming with minimum labour and investment are possible. An integrated tree forage-based livestock production system was introduced in 2000 and is considered a low-input technology. The systems use multipurpose leguminous trees and shrubs in marginal areas and wastelands around a farmstead in an agroforestry system for forage and livestock production in the small holder farming system. This paper reports the results of cultivation of multipurpose trees on feeding values in terms of livestock production and economic return in a smallholding integrated crop-livestock farming system.

\section{MATERIAL AND METHODS}

On average 100 mixed saplings of leucaena (Leucaena leucocephala), gliricidia (Gliricidia sepium) and calliandra (Caliandra calothyrsus) were planted as live fences in approximately $1.5 \mathrm{~m}$ spacing in and around homesteads, bunds and kitchen gardens and allowed to grow 3 years. These trees were used rotationally and each day one of the trees was completely pruned at 1.5-2 m height, and the yield of forage and fuel wood was measured. Representative freeze-dried forage and soil samples collected at $0-10 \mathrm{~cm}$ depth at the beginning and 6 years after planting were chemically analysed for composition. An in vitro gas production method was used to determine organic matter (OM) digestibility of forage samples. Each of twelve milking cows, weaned calves and growing goats with an average initial liveweight of 195, 34 and $10 \mathrm{~kg}$, respectively, belonging to different farmers were selected and divided into 2 groups. One of the groups had free access to grasses and offered mixed tree leaves at the rate of $30 \%$ of their feed requirement per day, while the other group remained as a control in the traditional feeding system of free grazing and rice straw for cattle over a 5-month period. Daily milk yield was recorded after complete hand milking and the calves and goats were weighed fortnightly.

The data were analysed as a completely randomized block design by analysis of variance by the STAT program of SAS version 6.03 (1988). 


\section{RESULTS AND DISCUSION}

A sustainable system of cropping in an agroforestry system is the use of leguminous trees and shrubs, grown simultaneously with crops. The farmers were sceptical of planting trees around crop fields and homesteads, believing that this would affect crop yield and cultivation of fruit trees. Plantation of forage trees around kitchen gardens, homesteads and waste land created a fodder bank in a farmstead giving a sustainable supply of foliage, a live fence and a source of fuel wood throughout the year. The advantage of the system is that once the trees are established they continue to produce high quality forage for ruminants which does not require extra land, capital, or labour.

The cumulative yields of forages for the sum of the 3 harvests/year over 3 years are shown in Table 1. Cultivation of forage trees in these systems provided on average $1.53 \mathrm{~kg}$ fresh leaves per pruning from each tree. Psyllid infestation in leucaena trees in winter (average $20^{\circ} \mathrm{C}$ ) was not observed to have an effect on leaf yield. Apart from dry months, in winter these trees regenerated more branches and coppice than in the rest of the year. Leaf and fuel wood production in the subsequent years after their establishment were higher in leucaena followed by calliandra and gliricidia $(\mathrm{P}<0.05)$. On average, the yield of fresh leaves, $\mathrm{DM}$ and protein from these three tree species was $7.1,2.23$ and $0.52 \mathrm{t} / \mathrm{ha} / \mathrm{yr}$, respectively. Additionally, farmers continuously benefited by producing on average $3 \mathrm{t} / \mathrm{ha} /$ $\mathrm{yr}$ of fuel wood which is equivalent to $34 \%$ of the requirement of a family for cooking. These trees in addition to forage and fuel wood production can improve agro-ecology in farms mean with different letters within same parameter differ significantly $\mathrm{P}<0.05$ ) through plantation. Application of this technology would bring $0.39 \mathrm{~m}$ ha of fallow land in the country under plantation to produce $4.9 \mathrm{~m}$ tons of fresh leaves ( $1.54 \mathrm{~m}$ tons DM) and $0.8 \mathrm{~m}$ ton of forage protein annually, sufficient to rear a head of cattle or 4 goats in every farm.

Table 1. Yield and composition of tree foliages

\begin{tabular}{|c|c|c|c|c|c|c|c|c|c|c|c|}
\hline \multirow[b]{2}{*}{$\begin{array}{l}\text { Tree } \\
\text { species }\end{array}$} & \multicolumn{4}{|c|}{ Yield,t/ha/year } & \multicolumn{7}{|c|}{ Composition, $\%$} \\
\hline & fresh & $\mathrm{DM}$ & $\mathrm{CP}$ & $\begin{array}{l}\text { fuel- } \\
\text { wood }\end{array}$ & $\mathrm{OM}$ & $\mathrm{CP}$ & NDF & $\mathrm{ADF}$ & TT & $\mathrm{CT}$ & OMD \\
\hline Leucaena & $8.1^{\mathrm{a}}$ & $2.5^{\mathrm{a}}$ & $0.59^{\mathrm{a}}$ & $3.7^{\mathrm{a}}$ & 89.2 & 25.3 & 36.3 & 23.4 & 7.4 & 0.9 & 62.8 \\
\hline Gliricidia & $5.9^{\mathrm{b}}$ & $1.9^{\mathrm{b}}$ & $0.45^{\mathrm{b}}$ & $2.3^{\mathrm{b}}$ & 88.7 & 25.7 & 29.8 & 24.7 & 5.2 & 0.7 & 59.7 \\
\hline Calliandra & $7.3^{\mathrm{a}}$ & $2.3^{\mathrm{a}}$ & $0.52^{\mathrm{a}}$ & $3.1^{\mathrm{a}}$ & 90.3 & 24.8 & 34.9 & 25.9 & 6.6 & 0.7 & 55.4 \\
\hline SEM & 0.54 & 0.06 & 0.043 & 0.21 & 7.25 & 0.51 & 4.43 & 3.21 & 0.54 & 0.03 & 1.58 \\
\hline
\end{tabular}

TT - total tannins, CT- condensed tannins; means with different letters wifhin same parameters differ significantly $(\mathrm{P}<0.05)$

The country is also facing the problem of soil degradation caused by continuous use of arable land for cereal crops. In this situation the use of these $\mathrm{N}$-fixing plants 
can bring favourable changes to soil properties by promoting soil conservation and reducing soil degradation. Table 2 illustrates the properties of the soil under plantation. Cultivation of legume forage trees incorporated organic residues, litter and improved organic carbon, nitrogen, phosphorus and sulphur in soil. Despite statistical insignificance, there appeared to be a difference in soil properties, probably due to the $36 \%$ higher OM in the soil. Analysis of soils in the plantation sites revealed that $\mathrm{pH}$ and $\mathrm{C}: \mathrm{N}$ were well maintained in stable form, the $\mathrm{N}$ content increased $40 \%$, available phosphorus and sulphur in the soil, by 14 and $20 \%$, respectively, all of these results demonstrate the benefits of plantation. Therefore, the longer the multipurpose leguminous plants are in the soil, the better the soil is in terms of its chemical and biological properties. Similar benefits were observed by cultivation of rice and mung bean along with legume trees (Miah et al., 1997; Haque et al., 2001) and multipurpose forage trees and shrubs around homesteads and as live fences (Alam et al., 2004).

Table 2. Soil composition at the plantation sites

\begin{tabular}{llccccc}
\hline Soil composition & $\mathrm{pH}$ & $\mathrm{OM}, \%$ & $\mathrm{~N}, \%$ & $\mathrm{C}: \mathrm{N}$ & $\mathrm{P}, \mathrm{ppm}$ & $\mathrm{S}, \mathrm{ppm}$ \\
\hline Before plantation & 6.3 & 1.1 & 0.05 & 14.2 & 46.2 & 18.4 \\
After 6 years of plantation & 6.7 & 1.5 & 0.07 & 14.7 & 52.5 & 22.0 \\
SEM & 0.36 & 0.08 & 0.004 & 0.77 & 6.25 & 2.06 \\
\hline
\end{tabular}

Table 3. Effect of feeding tree forages on livestock production and economic gain

\begin{tabular}{lccccc}
\hline \multirow{2}{*}{ Treatment } & Milkyield & \multicolumn{2}{c}{ Liveweight gain, g/d } & \multicolumn{2}{c}{ Economic gain, Taka/family } \\
\cline { 2 - 6 } & $1 / \mathrm{d}$ & calves & goats & livestock & trees \\
\hline Grass $+30 \%$ forage & $2.77^{\mathrm{a}}$ & $264^{\mathrm{a}}$ & $62^{\mathrm{a}}$ & $39000(\$ 565)^{\mathrm{a}}$ & $7026(\$ 102)$ \\
Grass + rice straw & $1.72^{\mathrm{b}}$ & $177^{\mathrm{b}}$ & $37^{\mathrm{b}}$ & $26334(380)^{\mathrm{b}}$ & - \\
SEM & 0.31 & 52.7 & 4.9 & 937 & \\
\hline
\end{tabular}

means with different letters within same parameter differ significantly $(\mathrm{P}<0.05)$

The values of nutrient contents and digestibility (Table 1) of these tree leaves point to their superior nutritive values. From the point of quality they can be used to supplement, especially as a source of protein, ruminants fed on low quality natural vegetation and rice straw. The concentration of tannins was found to be below $10 \%$, considered to be the level inhibiting ruminal fermentation of dietary protein and increasing postruminal digestion. The results of the feeding trial shown in Table 3 revealed significant increases in milk yield and growth of calves and goats $(\mathrm{P}<0.05)$ from supplementation of mixed leaves over from control feeds of rice straw and natural grown grasses. These improvements in milk production and liveweight gain were 54 and $41 \%$ higher compared with the national average. Therefore, the present findings demonstrated the importance of high quality forage supplementation to a conventional basal diet for increasing milk yield and liveweight gain in existing small holding farming systems. The results of increased 
productivity indicate that supplementation improved basal feed utilization and provided extra nutrients for the above gain. The nutritive value of the forages is reported to be excellent and shown to be productive in agroforestry systems with ruminants to supply high quality forage (Gutteridge and Shelton, 1994; Alam et al., 2004). Agroforestry and silvopastoral systems of foliage production from these trees can support rearing more animals and higher liveweight gain (Raynolds and Attah-Krah, 1986; Pratchett and Triglone, 1989). If leaves can be produced in large quantities the potential is still great to exploit these forages as a primary source of ruminant feeds. This trial also demonstrated that if a farmer plants 90 trees as a live fence and prunes rotationally one tree per day, he or she may produce high quality feed throughout the year at no extra cost.

The technology tested was considered to be closely compatible with the traditional socio-economy of the farmers. Traditional farmers are usually responsive to any intervention in the farming system that has the potential to provide monetary benefit. This effort was aimed at generating additional income alongside their existing farming systems, as the scope for improvement in this system is beyond their need for cash income from present improvement of the livestock rearing system. Yield of forage, fuel wood, milk production, liveweight gain, pole and live fence converted into monetary benefit as a result of forage tree plantation is given in Table 3. The monetary value of gain from tree, live fence, milk and liveweight and manure was higher $(\mathrm{P}<0.05)$ than non-plantation farmers and estimated to be $43 \%$ of additional gross income. Additionally, the system may create a good microenvironment and improve soil fertility to support food crop production, reduce production costs and make the system sustainable. Therefore, it is concluded that the agroforestry-based forage-livestock production system appears to be promising in the production of high quality animal food protein from legume forage. The technology has potential for improving soil properties, farm income and agro-ecology in farms through cultivation of multipurpose leguminous forage trees on fallow lands.

\section{REFERENCES}

Alam M.R., Jahiruddin Md., Islam M.S., 2004. Agroforestry for improving small holding farming system. In: M.R. Mosquera-Losada, J. McAdam, A. Rigueiro-Rodriguez (Editors). Silvopatoralism and Sustainable Land Management. CABI Publishing (UK), pp. 41-43

Gutteridge R.C., Shelton H.M., 1994. Animal production potential of agroforestry systems. In: J.W. Copland, A. Djajanegra, M. Sabrani (Editors). Agroforestry and Animal Production for Human Welfare. ACIAR, Canberra (Australia), pp. 7-16

Haque M.A., Ali M.I., Khan M.K., 2001. Effect of tree prunings on soil fertility and crop yield in alley cropping system. Pakistan J. Biol. Sci. 4, 647-650

Miah M.G., Garrity D.P., Aragon M.L., 1997. Effect of legume trees on soil chemical properties under agroforestry system. Ann. Bangladesh Agr. 7, 95-103 
Pratchett D., Triglone T., 1989. Prospects for leucaena on the Ord. West Aust. J. Agr. 30, 62-66

Raynolds L., Attah-Krah A.N., 1986. Alley farming with livestock. In: B.T. Kang, L. Reynolds (Editors). Alley Farming in the Humid and Sub Humid Tropics. Proceedings of an International Workshop held at Ibadan (Nigeria), pp. 22-36

SAS, 1988. Procedures Guide for Personal Computers. Version 6.03, SAS Institute Inc. Cary, NC 